УДК 159.9

DOI https://doi.org/10.32838/2709-3093/2021.1/08

Котлова Л.О.

Житомирський державний університет імені Івана Франка

Тичина I.M.

Житомирський державний університет імені Івана Франка

\title{
Дранківська А.П.
}

Житомирський державний університет імені Івана Франка

\section{ОСОБЛИВОСТІ ПСИХОЛОГІЧНОГО БЛАГОПОЛУЧЧЯ ОСОБИСТОСТІ З РІЗНИМИ ЗАХИСНИМИ МЕХАНІЗМАМИ}

Статтю присвячено проблемі психологічного благополуччя особистості з різними захисними механізмами. Відчуття благополуччя є одним із факторів, що сприяє активному залученню особистості у професійну діяльність, суспільні процеси, сприяє формуванню впевненості у власних силах. Встановлено, що одним із чинників, якіможуть впливати на психологічне благополуччя, є захисні механізми. Вони є несвідомими, завдяки їм ми заспокоюємося, м'якше сприймаємо травмуючий чинник, негатив, зменшуємо напруження. У структурі психологічного благополуччя виокремлено шість основних компонентів: автономію, навколишнє середовище, особистісне зростання, позитивні відносини, самоприйняття, життєві иілі.

За результатами дослідження за методикою «Шкали психологічного благополуччя» встановлено, щя у 24\% досліджуваних переважає шкала «Позитивні взаємини з іниими», що свідчить про вірність, надійність, емпатійність досліджуваних. Також високі бали отримано за шкалою «Автономія» (20\%) (самостійність та незалежність). Низькі результати за шкалою «Управління середовищем» (10\%), що свідчить про утруднення контролю зовнішньої діяльності, неможливість передбачати та контролювати майбутні події. Загальний рівень психологічного благополуччя у досліджуваних сягає середнього рівня.

Визначено, що найчастіше досліджувані використовуються такі види психологічного захисту, як: «Заперечення» (21\%) та "Компенсація» (18\%). Найменше відповідей стосувалося заміщення (7\%) та проєкиії (7\%). Загальна напруженість досліджуваних становить 68\% за норми 40-50\%. Це свідчить про наявність внутрішніх $і$ зовнішніх конфліктів, брак спокою та рівноваги, наявність негативних думок, спровокованих фруструючими діями і т. д. Результати корелячійного аналізу вказують на прямий середній зв'язок між відчуттям психологічного благополуччя та захисними механізмами.

Ключові слова: психологічне благополуччя, захисні механізми, психічне здоров'я.

Постановка проблеми. Поняття психологічного благополуччя нині є досить актуальним i популярним, оскільки передбачає врахування не тільки об'єктивних факторів продуктивності (таких як умови праці, професійна компетентність, досвід), але й більшою мірою суб'єктивних (наприклад, почуття задоволеності власним життям). Відчуття благополуччя $\epsilon$ одним із чинників, що сприяє активному залученню особистості у професійну діяльність, суспільні процеси, сприяє формуванню впевненості у власних силах.

Аналіз останніх досліджень і публікацій. Теоретичну основу поняття «психологічне благополуччя» закладено в дослідженнях Н. Бредберна, К. Ріфф як показник особистісної зрілості, гармонії особистості, самоактуалізації $[1 ; 14]$.
Одними дослідниками (Е. Дінер, К. Ріфф, А. Созонтов) суб'єктивне благополуччя розглядається як складник психологічного благополуччя [7; 14], іншими ж (Г. Пучкова, A. Salehinejad), навпаки, - психологічне благополуччя як частина суб' єктивного [5; 15]. В окремих роботах ці поняття трактуються як синонімічні (Н. Бредберн та інші) [1; 12]. Також увага приділяється дослідженням, які присвячено вивченню впливу генетичних факторів на індивідуальні відмінності у психологічному благополуччі. $€$ дослідження взаємозв'язку міжособистісних рис людини i суб'єктивного відчуття благополуччя. На важливості дослідження психологічного благополуччя вказують сучасні зарубіжні дослідження науковців (A. Salehinejad, R. Heun, J. Handuleh, J. Buitrago, M. Marsh) [12; 15]. 
Значний внесок у дослідження поняття «психологічного благополуччя» зробила К. Ріфф. Основним в її теорії $є$ виокремлення таких компонентів, як самосприйняття, позитивні взаємини 3 оточеннями, автономія та інше [14].

Аналізуючи різні дослідження, можна простежити два напрями вивчення поняття «психологічного благополуччя»: гедоністичний, де благополуччя розглядається як задоволеність незадоволеність (Н. Бредберн) [1]; евдемоністичний, де головна увага приділяється особистісному зростанню, самоактуалізації, саморозвитку (К. Ріфф) [14].

Захисні механізми є несвідомими, завдяки їм ми заспокоюємося, м'якше сприймаємо травмуючий чинник, негатив, зменшуємо напруження. Людина нерідко використовує ці механізми для уникнення проблем і часом зловживає ними, що спричиняє викривлене сприйняття реальності та неможливість повною мірою оцінити ситуацію. Виникають вони ще в ранньому дитинстві й розвиваються надалі під впливом зовнішніх чинників, соціуму, життєвих обставин, власного саморозвитку. Проблема захисних механізмів знайшла своє відображення у працях Р. Грановської, 3. Фройда, А. Фройд [3; 8;9].

3 позиції гештальттерапії І. Булюбаш розглядає такі захисні механізми, як: конфлюєнція, проєкція, інтроспекція, ретрофлексія, еготизм, дефлексія [2]. Однак, на думку вчених (R. Campos, A. Larsen's, H. Bøggild, J. Mortensen's, L. Foldager), не досить дослідженими залишаються проблеми психологічного благополуччя осіб із різними захисними механізмами $[13 ; 10]$.

Постановка завдання. Мета статті - на основі теоретичного обгрунтування сутності та чинників психологічного благополуччя визначити, емпірично дослідити взаємозв'язок відчуття психологічного благополуччя та захисних механізмів у людей різного віку.

Виклад основного матеріалу дослідження. 3 метою вивчення загального рівня психологічного благополуччя особистості з різними захисними механізмами було використано такі методи: теоретичні - аналіз психологічної літератури 3 проблеми дослідження; порівняння, класифікація, систематизація й узагальнення теоретичних та емпіричних даних для розкриття сутності понять «психологічне благополуччя», «захисні механізми», виокремлення чинників психологічного благополуччя; емпіричні - тестування: методика «Шкали психологічного благополуччя» (ШПБ), діагностика механізмів психологічного захисту (опитувальник Плутчика Келлермана Конте) [6]; методи статистичної обробки даних - кореляційний аналіз Пірсона. У дослідженні взяли участь 200 досліджуваних ранньої та середньої дорослості.

Для визначення психологічного благополуччя досліджуваних нами було використано методику «Шкали психологічного благополуччя» К. Ріфф [6].

За результатами нами встановлено, що у $24 \%$ досліджуваних переважає шкала «Позитивні взаємини з іншими», що може свідчити про те, що досліджувані мають довірливі та хороші стосунки 3 оточенням, вони емпатійні, тобто здатні співпереживати, розуміють, що хороші стосунки будуються на взаємних поступках у будь-чому. Також високі бали було отримано за шкалою «Автономія» (20\%), це вказує насамперед на самостійність і незалежність людини. Також такі результати ми можемо пов'язати з тим, що в дослідженні брали участь доволі дорослі та сформовані особистості (25-50 років), у яких є власна думка, своє сформоване «Я». Такі люди самостійно регулюють свою поведінку, а також оцінюють себе щодо власних особистих критеріїв. За шкалою «Самоприйняття» (18\%) людина з високими балами характеризується позитивним ставленням до себе, прийняттям себе, своїх як позитивних, так і негативних якостей. Високі бали за цією шкалою також можна пов'язати 3 тим, що досліджувані є вже сформованими особистостями, яким насамперед не важливо «показувати свої лише найкращі сторони» та сприймати їх, а важливо бути собою. За шкалою «Особистісне зростання» було отримано середні показники (16\%), що свідчить про самореалізацію досліджуваних, професійне становлення.

Середні показники було отримано за шкалою «Meтa» $(12 \%)$, що свідчить про те, що нині цей феномен не $\epsilon$ настільки важливим, щоб ставити його на перше місце й зосереджувати всю увагу. Можливо, це пов'язано 3 тим, що людина не може знайти себе, відповідно, і важко ставити мету. Також варто згадати, що сьогодні панує світова пандемія, яка «збила з пантелику» багатьох людей, і нині людям важко зосередитися на чомусь, окрім здоров'я.

Найнижчі бали отримано за шкалою «Управління середовищем» (10\%). Ці результати можна пов'язати 3 тим, що нині людям важко контролювати зовнішню діяльність, ефективно використовувати всі можливості, неможливо передбачити майбутні події. На мою думку, передусім це пов'язано з нестабільністю в країні та світі. 


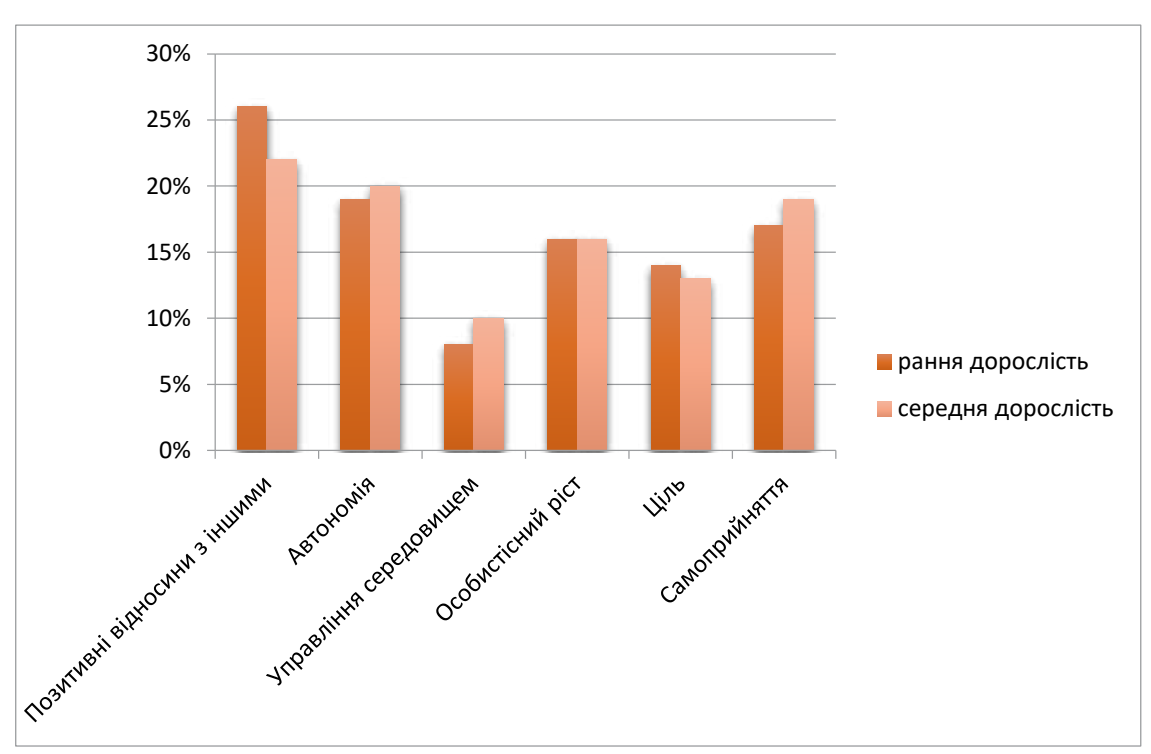

Рис. 1. Відмінності результатів за шкалами в досліджуваних ранньої та середньої дорослості

Проглядаючи результати дослідження за шкалами в людей ранньої та середньої дорослості, можемо сказати, що відрізняються результати за шкалою «Позитивні взаємини з іншими» на користь досліджуваним ранньої дорослості, оскільки налагодження позитивного контакту та наявність постійного кола спілкування в цьому віці є значно важливішим. За іншими шкалами значних відмінностей не встановлено (рис. 1).

Також доцільним є описати загальний рівень благополуччя досліджуваних, у 74\% досліджуваних переважає середній рівень психологічного благополуччя, що вказує на позитивне функціонування досліджуваних загалом і за окремими складниками конструкту психологічного благополуччя. У $12 \%$ досліджуваних низький рівень психологічного благополуччя. Це може бути пов'язано з високим рівнем тривожності, оскільки дослідження проводилося в період пандемії, коли в людей страх і переживання щодо здоров'я та життя загалом.

У 14\% досліджуваних високий рівень психологічного благополуччя, що свідчить про максимальну задоволеність життям, позитивним настроєм і мисленням.

Захисні механізми - підсвідома стратегія, яка захищає розум від відчуття неспокою. Захисні механізми якоюсь мірою викривлюють реальність для того, щоб людина мала змогу краще впоратися з певною ситуацією.

Діагностика захисних механізмів за допомогою методики Плутчика - Келлермана - Конте дає можливість опитати основні тенденції, які спостерігаються в досліджуваних. Серед досліджуваних найчастіше використовуються такі види психоло- гічного захисту: заперечення (у 21\% досліджуваних) та компенсація (18\%). Найменше відповідей стосувалося заміщення (7\%) та проєкції (7\%).

Заперечення, як механізм психологічного захисту, характеризується запереченнями людини усвідомлювати деякі фруструючі, тривожні обставини або який-небудь внутрішній імпульс. Зазвичай дія цього механізму проявляється в запереченні тих аспектів зовнішньої діяльності, які $€$ очевидними для оточення, а втім, не сприймаються самою особистістю. Інакше кажучи, інформація, яка $є$ тривожною та може призвести до конфлікту, не сприймається. Сьогодні цей механізм психологічного захисту можна пов'язати зі світовою пандемією. Люди відмовляються вірити в погане, у негативні наслідки, зокрема летальні. 3 огляду на це в більшості досліджуваних використовується цей захисний механізм. Компенсачія - захисний механізм психіки, що полягає в несвідомій чи свідомій спробі подолання реальних і уявних хиб, відновленні порушеної рівноваги психічних і психофізіологічних процесів шляхом створення протилежно спрямованої реакції або імпульсу. На мою думку, високі результати серед досліджуваних набрав, власне, цей механізм психологічного захисту через те, що більшість людей стараються компенсувати негативні емоції за допомогою позитивних дій, наслідків. Нині важко зосередитися тільки на одному позитиві, проте шукати шляхи розв'язання зовнішніх і внутрішніх проблем завжди гарне рішення.

Найменшу кількість серед усіх досліджуваних було отримано за шкалою «Заміщення», що свідчить про емоційну напругу, яка виникає під 
впливом фруструючої ситуації. Досліджувані можуть здійснювати неочікувані та зазвичай дії, які не мають сенсу для послаблення внутрішньої напруги. Також низькі результати за шкалою «Проєкиія». У буденному житті такий механізм можна описати прикладом, коли людина постійно приписує комусь іншому власні аморальні прагнення.

Отже, загальна напруженість досліджуваних становить $68 \%$. Це свідчить про наявність внутрішніх і зовнішніх конфліктів, відсутність спокою та рівноваги, наявність негативних думок, спровокованих фруструючими діями і т. д.

У досліджуваних середньої дорослості результати значно вищі, що свідчить про вищий ступінь заперечень фруструючих подій, досліджувані цієї категорії не хочуть сприймати та усвідомлювати наявну ситуацію. На противагу цьому досліджувані ранньої дорослості спокійніше ставляться до подій, незважаючи на те, позитивні чи негативні вони. Легше сприймають інформацію незалежно від ситуації.

Також можемо простежити значні відмінності за шкалою «Гіперкомпенсаиія», що свідчить про те, що люди старшого віку є більш тривожними та зазвичай перебільшують, особливо негативну інформацію. Цей вид психологічного захисту характеризується тим, що особистість запобігає вираженню неприємних або неприйнятних для неї думок, почуттів або вчинків шляхом перебільшеного розвитку протилежних прагнень.

Зашкалою «Регресія»вдосліджуванихіранньої, і середньої дорослості результати $є$ однаковими. Також можна побачити, що зазвичай вищі результати за цією методикою в досліджуваних ранньої дорослості. Можна говорити про більшу потребу використання механізмів психологічного захисту.

Отже, за результатами методики «Тест для діагностики механізмів психологічного захисту» Плутчика - Келлермана - Конте можемо зробити висновки. Серед загальних середніх показників усіх досліджуваних найбільше балів було отримано за шкалою «Заперечення». Загальний рівень напруженості досліджуваних становить 68\%.

Психологічний захист визначають як неусвідомлений психічний механізм, спрямований на мінімізацію негативних переживань людини через регуляцію іiї поведінки, підвищуючи іiі пристосованість і врівноважуючи психіку. Завдяки цьому рівень психологічного благополуччя буде вищим, оскільки людина задовольняє свої потреби, має позитивні думки.

Проаналізувавширезультатидіагностикизахисних механізмів і психологічного благополуччя, можемо зробити висновки. Згідно з результатами дослідження методики Плутчика - Келлермана Конте (рис. 3.5), ми з'ясували, що механізмами психологічного захисту, які найчастіше використовуються в житті досліджуваних, $є$ «Заперечення» $(21 \%)$ та «Компенсація» (18\%). Ці результати також переважали в досліджуваних із середнім і високим рівнем психологічного благополуччя.

У $74 \%$ досліджуваних рівень психологічного благополуччя $\epsilon$ на середньому рівні (за результатами методики «Шкали психологічного благополуччя» К. Ріфф). Найвищі бали за цією методикою було отримано за шкалами «Позитивні взаємини 3 іншими» $(24 \%)$ та «Автономія» $(20 \%)$. Також за цією методикою можемо простежити шкалу, за якою було отримано найменше балів - «Управління середовищем» $(10 \%)$.

Встановлено, що в досліджуваних, у яких рівень психологічного благополуччя є високим, позитивні відповіді за методикою діагностики захисних механізмів є вищими, аніж у тих, у кого рівень психологічного благополуччя $\epsilon$ низьким. Тобто, для того щоб забезпечити собі достатній рівень психологічного благополуччя, досліджувані змушені використовувати такі форми захисного реагування.

3 частиною досліджуваних було проведено бесіду, під час якої на запитання «Чому, на Вашу думку, Ви використовуєте механізми психологічного захисту?», більша частина відповіла, що так безпечніше та спокійніше. Захисні механізми функціонують на рівні несвідомого, видозмінюють об'єктивне бачення реальності, щоб мінімізувати тривогу для людини.

Результати кореляційного аналізу Пірсона показали наявність взаємозв'язку між відчуттям психологічного благополуччя та захисними механізмами $(0,48)$. У таблиці нижче наведено результати кореляції шкал психологічного благополуччя та захисних механізмів (табл. 1).

Таблиця 1

Показники кореляції шкал психологічного благополуччя та захисних механізмів особистості

\begin{tabular}{|c|c|}
\hline $\begin{array}{c}\text { Шкали психологічного } \\
\text { благополуччя }\end{array}$ & $\begin{array}{c}\text { Захисні } \\
\text { механізми }\end{array}$ \\
\hline Позитивні взаємини з іншими & $\mathrm{r}=0,53$ \\
\hline Автономія & $r=0,47$ \\
\hline Управління середовищем & $\mathrm{r}=0,48$ \\
\hline Особистісний ріст & $\mathrm{r}=0,51$ \\
\hline Мета & $\mathrm{r}=0,47$ \\
\hline Самоприйняття & $\mathrm{r}=0,44$ \\
\hline
\end{tabular}


За цими результатами можемо говорити про наявність середнього прямого зв'язку між змінними. У нашому випадку чим більше досліджувані використовують захисні механізми, тим вищий рівень психологічного благополуччя.

Висновки. Аналізуючи теоретичну базу поняття психологічного благополуччя та захисних механізмів, можна сказати, що захисні механізми психіки безпосереднім чином впливають на формування психологічного благополуччя через запобігання дезорганізації поведінки. Емпірична база цього дослідження дає змогу зробити висновки про наявність зв'язку між відчуттям психологічного благополуччя та захисними механізмами, оскільки, порівнявши результати механізмів психологічного захисту в досліджуваних із низьким і високим рівнем психологічного благополуччя, можна ска- зати, що результати є вищими в останніх. Результати кореляційного аналізу показали наявність взаємозв'язку між відчуттям психологічного благополуччя та захисними механізмами $(0,48)$. Це може свідчити про те, що феномен психологічного благополуччя $\epsilon$ досить мінливим і може змінюватися під впливом різних чинників. У нашому випадку досліджувані, у яких рівень використання захисних механізмів є високим, рівень психологічного благополуччя $є$ значно вищим, аніж у досліджуваних iз меншим використанням захисних механізмів.

Проведене дослідження не вичерпує всіх аспектів досліджуваної проблеми. Перспективами подальших досліджень вбачаємо розроблення, впровадження та перевірку ефективності програми підвищення рівня психологічного благополуччя особистості.

\section{Список літератури:}

1. Брэдберн Н. Структура психологического благополучия. Ярославль : Инфра, 2005. 13 с.

2. Булюбаш И.Д. Руководство по гештальт-терапии. Москва : Психотерапия, 2008. 768 с.

3. Грановская Р.М. Защита личности : психологические механизмы. Санкт-Петербург : Питер, 1999. $352 \mathrm{c}$.

4. Дубровина И.В. Психологическая служба в образовании. Психологическая наука и образование. 2001. № 2. С. 83-93.

5. Пучкова Г.Л. Субъективное благополучие как фактор самоактуализации личности : автореф. дисс. ... канд. психол. наук. Хабаровск, 2003. 24 с.

6. Реан А.А. Практическая психодиагностика личности. Санкт-Петербург, 2001.

7. Созонтов А.Е. Гедонистический и эвдемонистический подходы к проблеме психологического благополучия. Вопросы психологии. 2006. № 4. С. 105114.

8. Фрейд А. Психология Я и защитные механизмы. Москва : Педагогика-Пресс, 1993. 68 с.

9. Фрейд 3. Психология масс и анализ Я / пер. с нем. Р.Ф. Додельцева. Санкт-Петербург : Азбука-Аттикус, 2017. С. 269-270.

10. Anelia Larsen's, Henrik Bøggild, Jens Tølbøll Mortensen's, Leslie Foldager. Psychopathology, Defence Mechanisms, and the Psychosocial Work Environment. International Journal of Social Psychiatry. 2009. № 56(6). P. 563-77. DOI: 10.1177/0020764008099555.

11. Dupuy H.J. The psychological general well-being (PGWB) index. Wenger N.K., Mattson M.E., Furberg C.D., Elinson J. eds. Assessment of Quality of Life in Clinical Trials of Cardiovascular Therapies. New York, NY : Le Jacq Publishing, 1984. P. 170-183.

12. R. Heun, JIM Handuleh, JETG Buitrago, MS Marsh. High variability of the current mental health practices around the globe: Twenty days in the lives of psychiatrists and other mental health care professionals from all over the world. Global Psychiatry. 2020. Vol 3. Issue 2. DOI: 10.2478/gp-2020-0019.

13. Rui C Campos. Personality styles and defense mechanisms in a community sample of adolescents: An exploratory study. Bulletin of the Menninger Clinic. 2015. № 79 (1). P.14-40. DOI: 10.1521/bumc.2015.79.1.14.

14. Ryff C. Thestructureof psychological wellbeing revisited. Journal of Personality and Social Psychology. 1995. Vol. 69. P. 719-727.

15. Salehinejad A. Personality and Mental Health. Essential Notes in Psychiatry. 2012. DOI: 10.13140/ RG.2.1.1058.0003. 


\section{Kotlova L.O., Tychyna I.M., Drankivska A.P. FEATURES OF PSYCHOLOGICAL WELL-BEING OF} THE PERSON WITH VARIOUS PROTECTIVE MECHANISMS

The feeling of well-being is one of the factors that promotes the active inclusion of the individual in professional activities, social processes, contributes to the formation of self-confidence. One of the factors that can affect psychological well-being is protective mechanisms. They are unconscious, thanks to them we calm down, softer perceive the traumatic factor, the negative, reduce stress.

According to the results of the method "Scales of psychological well-being" K. Riff in 24\% of respondents is dominated by the scale "Positive relationships with others". Also, high scores were obtained on the scale "Autonomy" (20\%). The lowest scores were on the scale "Environmental Management" (10\%). The results on this scale are responsible for controlling external activities, future events, stability. The general level of psychological well-being in $74 \%$ of the subjects is at an average level.

According to the Plutchik-Kellerman-Conte method, the following types of psychological protection are most often used among all subjects: denial (21\%) and compensation (18\%). The lowest number among all subjects was obtained on the scale of "Substitution", which indicates the emotional stress that arises under the influence of a frustrating situation. Subjects may perform unexpected and usually actions that do not make sense to relieve internal tension.

The total intensity of the subjects is $68 \%$. This indicates the presence of internal and external conflicts, lack of peace and balance, the presence of negative thoughts provoked by frustrating actions, etc.

The results of the correlation analysis showed a relationship between the feeling of psychological well-being and protective mechanisms (0.48).

The practical significance lies in the development of a training program, the result of which we see an increase in the general level of psychological well-being, maintaining the integrity of the self-image and improving mental health.

Key words: defense mechanisms, mental health, psychological well-being, well-being, 